\title{
PENERAPAN METODE BALANCE SCORECARD SEBAGAI TOLOK UKUR PENILAIAN KINERJA PADA ORGANISASI SEKTOR PUBLIK (Studi Pada Dinas Pajak Daerah dan Pengelolaan Keuangan Kota Yogyakarta)
}

\author{
Yulaikah* \\ Sri Ayem \\ Program Studi Akuntansi, Fakultas Ekonomi \\ Universitas Sarjanawiyata Tamansiswa \\ *yulaikah_ust@yahoo.com
}

\begin{abstract}
Regional Tax Agency and Financial Management ( DPDPK) Yogyakarta is one of responsibility center in the structure organizations of local government that have an important role in budget planning and controlling. This study aims to assess the performance of DPDPK during 2009-2012 by using balanced scorecard. Balance scorecard is a performance measurement which is translated into four perspectives of performance, namely: the financial perspective, the perspective of local taxpayers, internal business process perspective and learning and growth perspectives.

Based on the analysis of performance measurement DPDPK Yogyakarta used the balanced scorecard method can be concluded that the DPPDK performance during the years of 20092012 considered quite good. Thereby the balance scorecard is suitable to be applied to the DPDPK Yogyakarta because it can provide a more structured and comprehensive in all aspects of the performance of both financial and non-financial organizations.
\end{abstract}

\section{Keywords : Performance Measurement, Balanced Scorecard, Public Sector, DPDPK}

\section{PENDAHULUAN}

Organisasi pemerintah pada era sekarang ini, baik pemerintah pusat maupun pemerintah daerah diharapkan untuk dapat menjadi akuntabel, kompetitif, ramah rakyat, dan berfokus pada kinerja. Organisasi pemerintah diminta untuk memenuhi harapan berbagai kelompok stakeholders yaitu penerima layanan, karyawan, lembaga pemberi pinjaman maupun hibah, masyarakat dan pembayar pajak. Tuntutan tersebut mengharuskan organisasi pemerintah untuk bertindak profesional sebagaimana yang dilakukan oleh organisasi swasta.

Untuk meningkatkan kinerja organisasi pemerintah/sektor publik, maka diperlukan suatu sistem berbasis kinerja. Kinerja yang baik harus mempunyai sistem pengukuran kinerja yang andal dan berkualitas, sehingga diperlukan penggunaan ukuran kinerja yang tidak hanya mengandalkan aspek keuangan saja tetapi juga memperhatikan aspek-aspek nonkeuangan. Konsep balanced scorecard yang dikembangkan oleh Kaplan dan Norton (1993) merupakan salah satu metode pengukuran kinerja dengan memasukkan empat aspek/perspektif di dalamnya yaitu: (1) perspektif keuangan; (2.) perspektif pelanggan; (3.) perspektif proses bisnis internal; serta (4.) perspektif pembelajaran dan pertumbuhan.

Dinas Pajak Daerah dan Pengelolaan Keuangan (DPDPK) Kota Yogyakarta merupakan unsur pemerintah daerah di bidang pajak daerah dan pengelolaan keuangan daerah. DPDPK merupakan salah satu pusat pertanggungjawaban dalam struktur organisasi pemerintah. Pusat-pusat pertanggungjawaban organisasi mempunyai 
peran yang sangat penting dalam melakukan perencanaan dan pengendalian anggaran. DPDPK yang menjadi salah satu pusat pendapatan daerah, memiliki peran dan tanggung jawab yang besar terhadap pengelolaan keuangan, pendapatan dan potensi daerah terutama pengoptimalan pendapatan dari pajak daerah.

Pengukuran kinerja sektor publik sangat penting untuk menilai akuntabilitas pemerintah daerah dalam melakukan pengelolaan keuangan daerah. Akuntabilitas bukan hanya sekedar kemampuan menunjukkan bagaimana uang publik dibelanjakan, akan tetapi meliputi kemampuan yang menunjukkan bahwa uang publik tersebut telah dibelanjakan secara ekonomis, efisien dan efektif serta manfaatnya dapat dirasakan oleh semua lapisan masyarakat.

Berdasarkan permasalahan tersebut, peneliti ingin mengaplikasikan pengukuran kinerja sektor publik dengan menggunakan metode balanced scorecard sehingga pengukuran kinerja tersebut dapat berimbang antara kinerja keuangan dan nonkeuangan, dan dapat mengukur apakah visi, misi dan strategi yang dijalankan sudah terealisasi sesuai keinginan, sehingga nantinya dapat diketahui apakah kinerja DPDPK Kota Yogyakarta selama ini sudah dapat dikatakan baik atau belum.

\section{RUMUSAN MASALAH}

Permasalahan yang akan dikaji dalam penelitian ini adalah :

1. Bagaimana penerapan balance scorecard pada organisasi sektor publik khususnya di Dinas Pajak Daerah dan Pengelolaan Keuangan Kota Yogyakarta?

2. Bagaimana hasil kinerja Dinas Pajak Daerah dan Pengelolaan Keuangan kota Yogyakarta bila diukur berdasarkan perspektif keuangan pada balance scorecard?

3. Bagaimana hasil kinerja Dinas Pajak Daerah dan Pengelolaan Keuangan kota Yogyakarta bila diukur berdasarkan perspektif wajib pajak daerah pada balance scorecard?

4. Bagaimana hasil kinerja Dinas Pajak Daerah dan Pengelolaan Keuangan kota Yogyakarta bila diukur berdasarkan perspektif proses bisnis internal pada balance scorecard?

5. Bagaimana hasil kinerja Dinas Pajak Daerah dan Pengelolaan Keuangan kota Yogyakarta bila diukur berdasarkan perspektif pertumbuhan dan pembelajaran pada balance scorecard?

\section{LANDASAN TEORI \\ Organisasi Sektor Publik}

Sektor publik adalah pemerintah (government) yang memiliki peran atau tugas untuk menyejahterakan masyarakatnya, dalam hal ini pemerintah sendiri diberi

dan menjamin pemenuhan kebutuhan barang dan jasa publik yang berdasarkan hukum. Organiasi sektor publik adalah organisasi yang berhubungan dengan kepentingan umum dan penyediaan barang atau jasa kepada publik yang dibayar melalui pajak atau pendapatan negara lain yang diatur dengan hukum (Mahsun, 2011).

\section{Pengukuran Kinerja Sektor Publik}

Pengukuran kinerja sektor publik dilakukan untuk memenuhi tiga maksud. Pertama, pengukuran kinerja sektor publik dimaksudkan untuk memperbaiki kinerja pemerintah. Ukuran kinerja dimaksudkan untuk dapat membantu pemerintah berfokus pada tujuan dan sasaran program unit kerja. Kedua, ukuran kinerja sektor publik digunakan untuk pengalokasian sumber daya dan pembuatan keputusan. Ketiga, ukuran kinerja sektor publik dimaksudkan untuk mewujudkan pertanggungjawaban publik dan memperbaiki komunikasi dengan pelanggan (Suwardika, 2011).

Pengukuran kinerja dapat disimpulkan sebagai suatu metode atau alat yang digunakan untuk menilai pencapaian pelaksanaan kegiatan berdasarkan rencana strategis sehingga dapat diketahui kemajuan 
organisasi serta untuk meningkatkan kualitas pengambilan keputusan dan akuntabilitas. Jadi, pengukuran kinerja adalah proses menilai kemajuan pencapaian tujuan dan sasaran yang telah ditetapkan oleh organisasi guna mendukung pencapaian misi organisasi, termasuk menilai efisiensi dan efektifitas dari aktivitas-aktivitas organisasi.

\section{Tujuan dan Manfaat Pengukuran Kinerja}

Pengukuran kinerja merupakan bagian penting dari proses pengendalian manajemen, baik orgisasi publik maupun swasta. Namun karena sifat dan karakteristik organisasi publik berbeda dengan sektor swasta, penekanan dan orientasi pengukuran kinerjanya pun terdapat perbedaan. Menurut Mahmudi (2010), tujuan dilakukan penilaian kinerja di sektor publik adalah; (1) Mengetahui tingkat ketercapaian tujuan organisasi; (2) Menyediakan sarana pembelajaran pegawai; (3) Memperbaiki kinerja periode berikutnya; (4) Memberikan pertimbangan yang sistematik dalam pembuatan keputusan pemberian reward dan punishment; (5) Memotivasi pegawai; dan (6) Menciptakan akuntabilitas publik.

Menurut Mardiasmo (2002) manfaat pengukuran kinerja sektor publik bagi pihak internal dan eksternal organisasi, antara lain; (1) Memberikan pemahaman mengenai ukuran yang digunakan untuk menilai kinerja manajemen; (2) Memberikan arah untuk mencapai kinerja yang telah ditetapkan; (3) Untuk memonitor dan mengevaluasi pencapaian kinerja dan membandingakan dengan target serta melakukan tindakan korektif untuk memperbaiki kinerja; (4) Sebagai dasar untuk memberikan penghargaan dan hukuman secara objektif atas pencapaian prestasi yang diukur sesuai dengan sistem pengukuran kinerja yang telah disepakati; (5) Sebagai alat komunikasi antara bawahan dan pimpinan dalam rangka memperbaiki kinerja organisasi; (6) Membantu mengidentifikasi apakah kepuasan pelanggan sudah terpenuhi; (7) Membantu memahami proses kegiatan instansi pemerintah; dan (8) Memastikan bahwa pengambilan keputusan dilakukan secara objektif.

\section{Balance Scorecard}

Pada awal sekitar tahun 90an, balanced scorecard ditemukan dan digunakan oleh Robert S. Kaplan dan David P. Norton sebagai alat pengukuran kinerja manajemen pada perusahaan-perusahaan swasta di Amerika. Secara harfiah, pengertian balanced scorecard dapat dibagi dua yaitu 'scorecard' yang diartikan bagian sebagai sebuah kartu laporan kinerja yang berisikan angka-angka dan yang artinya seimbang.

Kartu skor adalah kartu yang digunakan untuk mencatat skor hasil kinerja suatu organisasi atau skor individu. Melalui kartu skor, skor yang hendak diwujudkan organisasi atau individu di masa depan dibandingkan dengan hasil kinerja sesungguhnya. Hasil perbandingan tersebut digunakan untuk melakukan evaluasi atas kinerja organisasi atau individu yang bersangkutan. Kata berimbang dimaksudkan untuk menunjukkan bahwa kinerja organisasi atau individu diukur secara berimbang dari dua aspek yaitu keuangan dan nonkeuangan, jangka pendek dan jangka panjang, internal dan eksternal (Rahmawati, dkk., 2006 dan Pratiwi, 2010).

Menurut Kaplan dan Norton (1996) balanced scorecard adalah suatu kerangka kerja baru untuk mengintegrasikan berbagai ukuran yang diturunkan dari strategi perusahaan. Selain ukuran kinerja finansial masa lalu balanced scorecard juga memperkenalkan pendorong kinerja finansial masa depan yang meliputi: perspektif pelanggan, proses bisnis internal dan pembelajaran serta pertumbuhan yang diturunkan dari proses penerjemahan strategi perusahaan yang dilaksanakan secara eksplisit dan ketat kedalam berbagai tujuan dan ukuran nyata

Keunggulan Penerapan Balance Scorecard Dari berbagai literatur dapat disimpulkan bahwa keunggulan dalam penerapan balance 
scorecard pada suatu organisasi adalah sebagai berikut:

\section{Mencakup pengukuran nonfinansial dan sisi eksternal}

kinerja

Balanced scorecard mengukur kinerja nonfinansial melalui perpektif kepuasan pelanggan, bisnis internal dan pertumbuhan serta pembelajaran sedangkan pengukuran kinerja pada sisi eksternal adalah perspektif kepuasan pelanggan. Dengan demikian, balanced scorecard dipandang telah secara komprehensif mengukur kinerja suatu organisasi.

\section{Pengukuran kinerja yang koheren}

Maksudnya pengukuran kinerja dengan menggunakan balanced scorecard menunjukkan adanya hubungan sebab akibat antara masing-masing item ukuran kinerja yang diarahkan untuk mencapai visi organisasi.

\section{Penilaian kinerja yang terukur}

Semua sasaran strategis dapat diukur dengan jelas dengan menggunakan model balanced scorecard baik untuk perspektif yang bersifat kuantitaif maupun kualitatif.

\section{Keseimbangan dalam pengukuran \\ berbagai aspek kinerja}

Keseimbangan dalam perencanaan strategis diwujudkan kedalam kinerja setiap perspektif balanced scorecard baik untuk perencanaan jangka panjang atau pendek, aspek finansial atau nonfinansial, ukuran kinerja masa lalu atau kinerja masa yang akan datang serta sisi eksternal ataupun untuk internal organisasi.

\section{Balance Scorecard untuk Sektor Publik}

Pada awalnya balanced scorecard didesain untuk organisasi bisnis yang bergerak di sektor swasta, namun pada perkembangannya balanced scorecard dapat diterapkan pada organisasi sektor publik dan organisasi nonprofit lainnya. Tujuan utama sektor publik bukan berorientasi pada aspek finansial semata. Organisasi sektor publik mengukur keberhasilan melalui kemampuan mengatur pengeluaran sejumlah anggaran yang berwujud pada kebutuhan masyarakat, instansi pemerintah lain dan pemerintah pusat (stakeholders). Dengan demikian, fokus utama organisasi sektor publik bukan pada pencapaian tujuan finansial namun pada tujuan yang berfokus pada pelanggan yaitu masyarakat dan pemerintah pusat. Keberhasilan sektor publik diukur melalui efektivitas dan efisiensi dalam memenuhi kebutuhan stakeholders yang diwujudkan melalui tujuan-tujuan yang berwujud (tangibles objectives).

Tabel 1

\section{Perbedaan Perspektif Balanced Scorecard pada} Sektor Swasta dan Sektor Publik

\begin{tabular}{|c|c|c|}
\hline Perspektif & $\begin{array}{c}\text { Organisasi Swasta/Bisnis } \\
\text { (Private Sector) }\end{array}$ & $\begin{array}{c}\text { Organisasi Pemerintah (Public } \\
\text { Sector) }\end{array}$ \\
\hline Keuangan & $\begin{array}{l}\text { Bagaimana kita melihat dan } \\
\text { memberikan nilai kepada } \\
\text { pemegang saham? }\end{array}$ & $\begin{array}{l}\text { Bagaimana kita melihat dan } \\
\text { memberikan nilai kepada } \\
\text { masyarakat dan/atau pembayar } \\
\text { pajak? }\end{array}$ \\
\hline Pelanggan & $\begin{array}{l}\text { Bagaimana pelanggan melihat } \\
\text { dan mengevaluasi kinerja kita? }\end{array}$ & $\begin{array}{l}\text { Bagaimana masyarakat pengguna } \\
\text { layanan publik melihat dan } \\
\text { mengevaluasi kinerja kita? }\end{array}$ \\
\hline Proses Internal & $\begin{array}{l}\text { Apa yang harus diunggulkan } \\
\text { dari proses dan produk kita? }\end{array}$ & $\begin{array}{l}\text { Apakah program-program } \\
\text { pembangunan yang dilaksanakan } \\
\text { telah memberikan hasil-hasil } \\
\text { sesuai dengan yang } \\
\text { diinginkan/diharapkan? }\end{array}$ \\
\hline
\end{tabular}




\begin{tabular}{lll}
\hline Pertumbuhan & Dapatkah kita melanjutkan & Dapatkah kita melanjutkan untuk \\
dan & untuk meningkatkan dan & meningkatkan dan menciptakan \\
Pembelajaran & menciptakan nilai kepada & nilai untuk masyarakat/pembayar \\
& pelanggan, pemegang saham, & pajak, aparatur dan pejabat, \\
& $\begin{array}{l}\text { karyawan, manajemen serta } \\
\text { organisasi? }\end{array}$ & organisasi pemerintah, dan \\
& stakeholders. \\
\hline
\end{tabular}

Sumber : Gaspersz, 2006

Organisasi sektor publik menempatkan perpektif pelanggan sebagai prioritas utama dalam menjalankan organisasi, artinya strategi organisasi sektor publik akan ditujukan untuk peningkatan pelayanan publik. Setiap target kinerja pada perspektif keuangan, bisnis internal dan pertumbuhan serta pembelajaran akan diarahkan pada upaya-upaya peningkatan kepuasan pelanggan/publik, tolok ukur sukses atau gagalnya penyelengaraan suatu layanan publik adalah kepuasan publik. Keberhasilan organisasi sektor publik yang diukur melalui efektivitas dan efisisensi dalam memberikan pelayanan kepada masyarakat membuat organisasi sektor publik perlu menetapkan indikator-indikator dan target pengukuran kinerja yang berorientasi kepada masyarakat. Pengukuran kinerja tersebut dapat meningkatkan pertanggungjawaban dan memperbaiki proses pengambilan keputusan. Dengan demikian strategy mapping balanced scorecard pada organisasi sektor publik tersaji menjadi seperti yang terlihat pada gambar 1 .

Gambar 1.

\section{Strategy Mapping Balanced Scorecard}

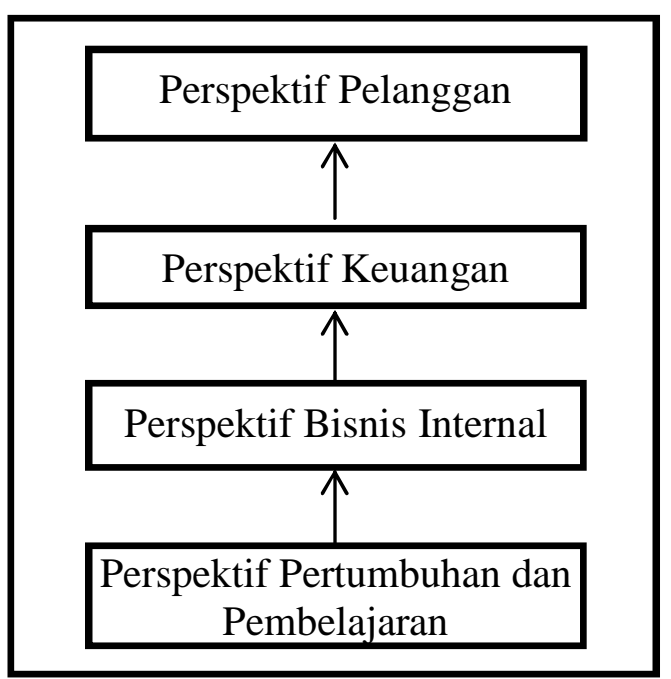

Pada Organisasi Sektor Publik

(Sumber: Robertson dalam Mahsun, 2009)

\section{Tujuan dan Manfaat Penerapan Balance Scorecard Pada Sektor Publik}

Tujuan penerapan balanced scorecard pada pengukuran kinerja organisasi publik adalah untuk menyatakan adanya keseimbangan antara berbagai ukuran internal dan eksternal untuk menghasilkan berbagai proses manajemen penting (Sari, 2013) yaitu: (1) memperjelas dan menerjemahkan misi dan strategi organisasi; (2) mengkomunikasikan dan mengaitkan berbagai tujuan dan ukuran strategis; (3) merencanakan dan menetapkan sasaran untuk menyelaraskan berbagai inisiatif organisasi; dan (4) meningkatkan umpan balik dan pembelajaran utamanya didalam membenahi strategis organisasi menuju pelayanan yang lebih baik.

Melalui sistem pengukuran kinerja balance scorecard, organisasi pemerintah akan mampu menjelaskan misinya kepada masyarakat dan dapat mengidentifikasi indikator kepuasan masyarakat secara lebih transparan, objektif dan terukur serta mampu mengidentifikasi proses kerja dan kualitas sumber daya manusia yang dibutuhkan dalam mencapai misi dan strateginya. Ada beberapa manfaat bagi organisasi sektor publik jika menggunakan balanced scorecard, (Oskar, 2007) dalam Sari (2013) yaitu: (1) balance scorecard menempatkan seluruh organisasi dalam proses pembelajaran; (2) keputusan penganggaran menjadi lebih rasional; (3) memfasilitasi perbaikan kinerja; (4) memperbaiki komunikasi kepada stakeholders; memberikan data untuk acuan. 


\section{METODE PENELITIAN \\ Sifat Penelitian}

Berdasarkan fungsinya, penelitian ini termasuk penelitian evaluatif. Penelitian evaluatif dimaksudkan untuk mengukur keberhasilan suatu program, produk atau kegiatan tertentu (Danim, 2000).

Tujuan penelitian evaluatif adalah untuk mengetahui keterlaksanaan kebijakan, bukan hanya pada kesimpulan sudah terlaksana dengan baik atau tidaknya, tetapi ingin mengetahui kalau belum baik implementasinya, apa yang menjadi penyebabnya, terletak dimana titik kelemahannya dan kalau lemah apa sebabnya. Dengan adanya penelitian evaluatif, maka sebuah lembaga dapat ditingkatkan mutu kinerjanya, atau dengan kata lain penelitian evaluatif ini mempunyai manfaat sebagai pengembangan kualitas (Arikunto, 2010: 37).

\section{Ruang Lingkup dan Lokasi Penelitian}

Penelitian ini merupakan studi kasus yaitu pengumpulan data dengan mengambil beberapa elemen dan kemudian masingmasing elemen diteliti dan dianalisis, kesimpulan yang dihasilkan hanya berlaku untuk elemen-elemen yang diteliti saja.

Penelitian ini dilakukan di Dinas Pajak Daerah dan Pengelolaan Keuangan (DPDPK) Kota Yogyakarta. Pemilihan lokasi penelitian dilakukan secara sengaja (purposive) dengan pertimbangan bahwa objek penelitian dianggap relevan dengan permasalahan yang diteliti.

\section{Variabel Penelitian}

Berikut adalah tabel tolok ukur penilaian kinerja DPDPK Kota Yogyakarta dengan metode balance scorecard:

Tabel 2.

Tolok Ukur Pengukuran Kinerja DPDPK Kota Yogyakarta Dengan Metode Balance Scorecard

\begin{tabular}{|c|c|c|c|}
\hline No & Perspektif & Tolok Ukur & Sasaran Strategis \\
\hline 1. & Keuangan & $\begin{array}{l}\text { a. Rasio Ekonomis } \\
\text { b. Rasio Efektivitas } \\
\text { c. Rasio Efisiensi }\end{array}$ & $\begin{array}{l}\text { Menigkatnya efektivitas dan } \\
\text { efisiensi belanja daerah. } \\
\text { Mengembangkan pengelolaan } \\
\text { keuangan daerah secara efektif, } \\
\text { efisien, transparan dan } \\
\text { akuntabel. }\end{array}$ \\
\hline 2. & $\begin{array}{l}\text { Masyarakat } \\
\text { Pembayar } \\
\text { Pajak }\end{array}$ & $\begin{array}{l}\text { a. Akuisisi Wajib Pajak } \\
\text { (WP) Daerah } \\
\text { b. Retensi WP Daerah } \\
\text { c. Kepuasan WP Daerah }\end{array}$ & $\begin{array}{l}\text { Tingkat kepatuhan wajib pajak } \\
\text { daerah bertambah. } \\
\text { Meningkatnya pendapatan } \\
\text { daerah. }\end{array}$ \\
\hline 3. & $\begin{array}{l}\text { Proses Bisnis } \\
\text { Internal }\end{array}$ & $\begin{array}{l}\text { a. Sarana dan Prasarana } \\
\text { b. Proses } \\
\text { c. Kepuasan Bekerja }\end{array}$ & $\begin{array}{l}\text { Peningkatan pelayanan kepada } \\
\text { masyarakat/wajib pajak daerah } \\
\text {-Peningkatan kualitas bekerja } \\
\text { pegawai }\end{array}$ \\
\hline 4. & $\begin{array}{l}\text { Pertumbuhan } \\
\text { dan } \\
\text { Pembelajaran }\end{array}$ & $\begin{array}{l}\text { a. Retensi Pegawai } \\
\text { b. Motivasi Kerja } \\
\text { c. Kesempatan } \\
\text { Mengembangkan Diri } \\
\text { d. Inovasi } \\
\text { e. Suasana Bekerja }\end{array}$ & $\begin{array}{l}\text { Berkurangnya jumlah } \\
\text { pegawai yang keluar } \\
\text { Tingkat waktu penyelesain } \\
\text { pekerjaan lebih cepat } \\
\text {-Terciptanya iklim kerja yang } \\
\text { kondusif dan menyengankan. }\end{array}$ \\
\hline
\end{tabular}

Sumber: Hasil analisis, 2013

\section{Jenis dan Sumber Data}

Sumber data dalam penelitian adalah subjek dari mana data dapat diperoleh (Arikunto,
2010:172). Data yang digunakan dalam penelitian ini adalah berupa data primer dan data sekunder. Data primer dalam penelitian 
ini diperoleh dengan cara wawancara langsung (tidak terstruktur) dengan beberapa pegawai yang terkait secara langsung dengan data dalam penelitian dan penyebaran kuesioner kepada beberapa pegawai dinas pada setiap bagian atau unit kerja.

Data sekunder yang digunakan dalam penelitian ini antara lain: mengambil dan mengolah data yang sudah ada, yakni dokumen-dokumen yang dimiliki oleh organisasi seperti: struktur organisasi, data mengenai laporan keuangan organisasi, data mengenai jumlah pelanggan wajib pajak daerah serta data pendukung lainnya.

\section{Metode Pengumpulan Data}

Metode pengumpulan data dalam penelitian ini antara lain dilakukan dengan melakukan wawancara (tidak terstruktur) dengan bagianbagian yang terkait dengan pembahasan dalam penelitian ini. Selain itu, metode pengumpulan data juga dilakukan dengan membagikan kuesioner kepada 40 pegawai DPDPK yang nantinya hasil pengolahan kuesioner tersebut digunakan untuk mengukur kinerja organisasi dari perspektif proses bisnis internal serta perspektif pertumbuhan dan pembelajaran. Kemudian untuk metode dokumentasi dalam penelitian ini dilakukan dengan mengumpulkan data keuangan (anggaran dan realisasi anggaran) serta data yang mencakup perspektif wajib pajak daerah dan perspektif proses bisnis internal.

\section{Skala dan Instrumen Penelitian}

Skala pengukuran merupakan kesepakatan yang digunakan sebagai acuan untuk menentukan panjang pendeknya interval yang ada dalam alat ukur, sehingga alat ukur tersebut bila digunakan dalam pengukuran akan menghasilkan data kuantitatif. Sedangkan alat ukur yang digunakan dalam penelitian tersebut dinamakan instrumen penelitian (Sugiyono, 2010).

Dalam penelitian ini, penulis menggunakan skala likert dengan interval 1-5 sebagai skala pengukuran untuk menilai sikap, pendapat maupun persepsi seseorang atau sekelompok orang terhadap kinerja DPDPK Kota Yogyakarta dengan metode balance scorecard. Sedangkan instrumen penelitian yang digunakan adalah teknik analisis rasio keuangan (value for money) untuk perspektif keuangan, analisis persentase akusisi, retensi serta kepuasan wajib pajak daerah (WPD) untuk perspektif WPD serta kuesioner untuk perspektif proses bisnis internal serta perspektif pertumbuhan dan pembelajaran. Pada tabel berikut disajikan penjelasan untuk masing-masing skala pengukuran yang dimaksud.

\section{Skala Pengukuran Perspektif Keuangan}

Tabel 3

Skala Pengukuran Perspektif Keuangan

\begin{tabular}{ccc}
\hline $\begin{array}{c}\text { Skala Kinerja } \\
\text { Keuangan }\end{array}$ & Nilai Konversi & Kategori \\
\hline RASIO EKONOMIS & 5 & Sangat Ekonomis \\
$<80 \%$ & 4 & Ekonomis \\
$80 \%-85 \%$ & 3 & Cukup Ekonomis \\
$85 \%-90 \%$ & 2 & Tidak Ekonomis \\
$90 \%-95 \%$ & 1 & Sangat Tidak Ekonomis \\
$>95 \%$ & & Sangat Efektif \\
RASIO EFEKTIVITAS & 5 & Efektif \\
$>95 \%$ & 4 & Cukup Efektif \\
$80 \%-95 \%$ & 3 & Tidak Efektif \\
$65 \%-80 \%$ & 2 & Sangat Tidak Efektif \\
$50 \%-65 \%$ & 1 & \\
$<50 \%$ &
\end{tabular}




\begin{tabular}{ccc}
\hline RASIO EFISIENSI & & \\
$<100 \%$ & 5 & Sangat Efisien \\
$100 \%-110 \%$ & 4 & Efisien \\
$110 \%-120 \%$ & 3 & Cukup Efisien \\
$120 \%-130 \%$ & 2 & Tidak Efisien \\
$>130 \%$ & 1 & Sangat Tidak Efisien \\
\hline
\end{tabular}

Sumber : Sugiyono, 2010, diolah kembali.

\section{Skala Pengukuran Perspektif Masyarakat Pembayar Pajak (WPD)}

Tabel 4

Skala Pengukuran Perspektif WPD

\begin{tabular}{ccc}
\hline Skala Kepuasan WPD & Nilai Konversi & Kategori \\
\hline AKUSISI WPD & 5 & Baik \\
Peningkatan & 3 & Sedang \\
Konstan/Fluktuatif & 1 & Kurang \\
Menurun & & \\
RETENSI WPD & 5 & Baik \\
Peningkatan & 3 & Sedang \\
Konstan/Fluktuatif & 1 & Kurang \\
Menurun & & \\
KEPUASAN WPD & 5 & Sangat Baik \\
$81,26-100,00$ & 4 & Baik \\
$62,51-81,25$ & 3 & Kurang Baik \\
$43,76-\quad 62,50$ & 2 & Tidak Baik \\
$25,00-43,75$ & 1 & Sangat Tidak Baik \\
$<25,00$ & \multicolumn{2}{c}{}
\end{tabular}

\section{Skala Pengukuran Perspektif Kuesioner}

\section{Tabel 5}

Skala Pengukuran Kuesioner

\begin{tabular}{cc}
\hline Skala & Kategori \\
\hline 5 & Sangat Setuju/Sangat Puas \\
4 & Setuju/Puas \\
3 & Cukup Setuju/Cukup Puas \\
2 & Tidak Setuju/Tidak Puas \\
1 & Sangat Tidak Setuju/Sangat Tidak Puas \\
\hline Sumber : Sugiyono, 2010, diolah kembali.
\end{tabular}

\section{Populasi dan Sampel}

Populasi dalam penelitian ini adalah seluruh pegawai pada DPDPK Kota Yogyakarta. Sampel untuk kuesioner dalam penelitian ini berjumlah 40 responden dari populasi sebanyak 140 jumlah pegawai pada DPDPK Kota Yogyakarta pada tahun 2013. Hasil pengolahan kuesioner tersebut dijadikan dasar untuk menilai kinerja DPDPK dari perspektif proses bisnis internal serta perspektif pertumbuhan dan pembelajaran

\section{Pengujian Instrumen Penelitian}

Pengujian ini dilakukan untuk menguji kuesioner yang nantinya digunakan untuk mengukur kinerja DPDPK berdasarkan perspektif proses bisnis internal serta perspektif pertumbuhan dan pembelajaran. Data diuji dengan menggunakan SPSS versi 16.0. Penelitian diharapkan dapat memperoleh hasil yang objektif (valid) dan dapat diuji konsistensinya (reliability). 
Pengujian dengan menggunakan uji validitas dengan menggunakan rumus korelasi product moment (Pearson) yaitu, pertanyaan dinyatakan valid jika $r$ hitung lebih besar dari $\mathrm{r}$ tabel. Nilai $\mathrm{r}$ tabel dalam penelitian ini adalah 0,312 dengan degree of fredom (df) sebesar 5\% atau 0,05 sedangkan uji reliabilitas menggunakan Alpha dengan nilai Croanbach's Alpha > 70\% (Ghozali: 2011).

\section{Metode Analisis Data}

Metode analisis data yang digunakan dalam penelitian ini adalah analisis deskriptif kuantitatif dan kualitatif yaitu peneliti melakukan pengumpulan data yang terdiri dari data keuangan dan nonkeuangan, kemudian mengolah data, menganalisis data dan mengambil kesimpulan. Dengan menggunakan skala likert pada interval 1-5 maka nilai kinerja akhir DPDPK Kota Yogyakarta dapat mencerminkan kategori kinerja yang telah ditetapkan sebagaimana terlihat pada tabel berikut:

\section{Tabel 6}

Penilaian Akhir Kinerja Balance Scorecard

\begin{tabular}{ccc}
\multicolumn{3}{c}{ Scorecard } \\
\hline Nilai & Skala & Kategori \\
\hline$>90 \%$ & 5 & Sangat Baik \\
$80 \%-90 \%$ & $4-4,9$ & Baik \\
$70 \%-80 \%$ & $3-3,9$ & Cukup Baik \\
$60 \%-70 \%$ & $2-2,9$ & Tidak Baik \\
$<60 \%$ & $1-1,9$ & Sangat Tidak \\
& & Baik \\
\hline
\end{tabular}

Sumber : Sugiyono, 2010, diolah kembali

\section{PEMBAHASAN}

\section{Deskripsi Objek Penelitian}

Dinas Pajak Daerah dan Pengelolaan Keuangan (DPDPK) Kota Yogyakarta merupakan unsur pelaksana pemerintah daerah di bidang pajak daerah dan pengelolaan keuangan daerah yang dipimpin oleh seorang kepala dinas yang berkedudukan di bawah dan bertanggung jawab kepada walikota melalui sekretaris daerah. DPDPK mempunyai tugas pokok melaksanakan urusan pemerintahan daerah berdasarkan asas otonomi dan tugas pembantuan di bidang pajak daerah dan pengelolaan keuangan daerah.

Visi DPDPK adalah "Menjadi fasilitator dan motivator pengelolaan pajak daerah dan keuangan daerah yang efektif, efisien, transparan dan accountable untuk mendukung ketatalaksanaan pemerintah daerah yang berkualitas". Sedangkan misi DPDPK yaitu "Mewujudkan peningkatan pelayanan dan pendapatan daerah melalui pajak daerah dan mewujudkan peningkatan dan pengembangan pengelolaan keuangan daerah yang efektif, efisien, transparan dan accountable

\section{Pengukuran Kinerja DPDPK Kota Yogyakarta Dengan Metode Balance Scorecard}

\section{Perspektif Keuangan}

Seperti yang tercantum dalam balance scorecard DPDPK Kota Yogyakarta, sasaran strategik untuk perspektif keuangan adalah tercapainya efektivitas dan efesiensi penggunaan dana. Pengukuran yang akan dilakukan dalam perspektif ini ditujukan untuk melihat bagaimana keberhasilan DPDPK Kota Yogyakarta dalam mengelola anggaran belanja dan pendapatannya. Penilaian perspektif keuangan dilakukan dengan mengggunakan perhitungan analisis rasio ekonomis, efektivitas dan efisiensi (value for money) dengan membandingkan jumlah anggaran belanja dan pendapatan DPDPK. 
Rekapitualasi hasil nilai kinerja perspektif

keuangan terlihat pada tabel 7 berikut:

Tabel 7

Rekapitulasi Nilai Kinerja Perspektif Keuagan DPDPK Kota Yogyakarta

\begin{tabular}{ccccc}
\hline Tahun & Rasio Ekonomis & Rasio Efektivitas & Rasio Efisiensi & Jumlah \\
\hline 2009 & $86,45 \%$ & $102,41 \%$ & $16,93 \%$ \\
2010 & $91,50 \%$ & $98,81 \%$ & $12,05 \%$ & \\
2011 & $89,37 \%$ & $103,32 \%$ & $13,15 \%$ & \\
2012 & $84,13 \%$ & $105,45 \%$ & $9,74 \%$ & \\
Rata-rata & $\mathbf{8 7 , 8 6 \%}$ & $\mathbf{1 0 2 , 5 0 \%}$ & $\mathbf{1 2 , 9 8 \%}$ & Sangat Efisien \\
& Cukup Ekonomis & Sangat Efektif & $\mathbf{5}$ & $\mathbf{4 , 3 3}$ \\
Nilai & $\mathbf{3}$ & $\mathbf{5}$ & $\mathbf{B a i k}$ \\
\hline \multicolumn{4}{c}{ Skor Rata-rata } \\
\hline Kategori
\end{tabular}

Rata-rata rasio ekonomis selama empat tahun berturut-turut yaitu tahun 2009-2012 adalah sebesar $87,86 \%$, hal tersebut menunjukkan bahwa selama tahun 2009-2012 DPDPK telah melakukan penghematan belanja dinas sebesar 12,30\% atau sebesar $\mathrm{Rp}$ 58.813.740.744,00 (selisih antara anggaran belanja dan realisasi belanja) dari total anggaran belanja dinas. Dengan demikian, dapat disimpulkan bahwa kinerja DPDPK Kota Yogyakarta selama empat tahun tersebut cukup ekonomis karena persentase rasionya berada diantara $85 \%-90 \%$. Dengan menggunakan skala likert maka nilai untuk rasio ekonomis adalah $\mathbf{3}$ dan termasuk dalam kategori cukup ekonomis.

Rasio efektivitas pada tahun anggaran 2009 ke tahun anggaran 2010 mengalami penurunan sebanyak $3,6 \%$ dan pada tahun anggaran 2010 ke tahun anggaran 2011 mengalami kenaikan sebanyak 4,51. Sedangkan pada tahun anggaran 2012 kembali mengalami kenaikan sebesar 2,13\%. Rata-rata rasio efektivitas selama empat tahun berturut-turut yaitu tahun 2009-2012 adalah sebesar $102,50 \%$, artinya DPDPK mampu menghasilkan pendapatan sebanyak 1,03 kali dari yang ditargetkan. Sehingga dapat disimpulkan bahwa kinerja DPDPK
Kota Yogyakarta selama empat tahun tersebut sangat efektif karena persentase rasionya lebih dari 95\%. Dengan menggunakan skala likert maka nilai untuk rasio efektivitas DPDPK adalah $\mathbf{5}$ dan termasuk kategori sangat efektif.

Rasio efiseinsi pada tahun anggaran 2009 ke tahun anggaran 2010 mengalami penurunan sebanyak 4,88\% dan pada tahun anggaran 2010 ke tahun anggaran 2011 mengalami kenaikan sebanyak 1,2\%. Sedangkan pada tahun anggaran 2012 mengalami penurunan sebesar $3,51 \%$. Rata-rata rasio efisiensi selama empat tahun berturut-turut yaitu tahun 2009-2012 adalah sebesar 12,99\%, sehingga dapat disimpulkan bahwa kinerja DPDPK Kota Yogykarta selama empat tahun tersebut sangat efisien karena persentase rasionya kurang dari $100 \%$. Dengan menggunakan skala likert maka nilai untuk rasio efisensi adalah 5 dan termasuk dalam kategori sangat efisien.

Berdasarkan penilaian kinerja keuangan DPDPK Kota Yogyakarta dengan menggunakan metode analisis value for money tersebut, maka secara umum dapat disimpulkan bahwa kinerja DPDPK dari perspektif keuangan dianggap baik dengan 
nilai rata-rata sebesar $\mathbf{4 , 3 3}$ sebagaimana terlihat pada tabel 7 tersebut.

\section{Perspektif Masyarakat Pembayar Pajak (Wajib Pajak Daerah/WPD)}

Untuk melaukan penilaian kinerja perspektif wajib pajak daerah dilakukan dengan menggunakan 3 variabel tolok ukur yaitu akuisisi WPD, retensi WPD dan kepuasan WPD. Akuisisi WPD merupakan kemampuan organisasi dalam memperoleh WPD baru. Hal tersebut dapat dilihat dari persentase tambahan wajib pajak daerah yang berhasil diperoleh DPDPK Kota Yogyakarta. Dari jumlah wajib pajak daerah Kota Yogyakarta selama tahun 2009-2012 diketahui bahwa terjadi kenaikan jumlah pajak dari tahun ke tahun, namun jumlah WPD baru dari tahun ke tahun sendiri mengalami penurunan. Hal tersebut menunjukkan bahwa akuisisi wajib pajak daerah DPDPK tahun 2010-2012 dinilai kurang dan diberi skor $\mathbf{1}$.

Retensi WPD digunakan untuk mengukur tingkat dimana DPDPK Kota Yogyakarta dapat mempertahankan hubungan dengan wajib pajak daerah. Dari perhitungan jumlah kenaikan atau penurunan WPD Kota Yogyakarta diketahui bahwa persentase retensi WPD menunjukkan angka pertumbuhan dari tahun 2010-2011 sebesar $100 \%$ artinya DPDPK mampu mempertahankan semua wajib pajaknya bahkan berhasil menarik wajib pajak baru. Hal tersebut dibuktikan dengan meningkatnya jumlah wajib pajak setiap tahunnya meskipun pada tahun 2012 retensi WPD mengalami penurunan sebesar 3,44\%. Namun demikian secara keseluruhan, tingkat retensi wajib pajak daerah DPDPK dalam kurun waktu 2009 hingga 2012 dinilai baik dan diberi skor 5 .

Untuk mengukur tingkat kepuasan masyarakat/wajib pajak daerah (WPD), pada tahun 2013 Unit pelayanan bidang pajak daerah melakukan survei dengan menyebar kuesioner kepada 150 wajib pajak daerah sebagai responden. Hasil Indeks Kepuasan Masyarakat (IKM) unit pelayanan bidang pajak daerah menunjukkan bahwa masyarakat merasa puas dengan pelayanan yang diberikan oleh unit pelayanan bidang pajak daerah DPDPK Kota Yogyakarta dengan nilai sebesar $\mathbf{7 9 , 4 5}$ dan termasuk kategori baik. Tingkat kepuasan WPD juga dapat dinilai dari jumlah kenaikan (penurunan) pendapatan asli daerah yang berupa realisasi pajak daerah selama 4 tahun berturut-turut yaitu dari tahun 2009-2012. Data realisasi pajak daerah menunjukkan bahwa realisasi pajak daerah terus meningkat dari tahun 2009 sampai dengan tahun 2012 dengan peningkatan sebesar $8,18 \%, 35,04 \%$ dan $73,35 \%$ atau rata-rata pertumbuhan berdasarkan tahun dasar 2009 sebesar $38,86 \%$.

Berdasarkan pembahasan tiap variabel tingkat kepuasan WPD tersebut, maka secara keseluruhan penilaian kinerja perspektif WPD dikategorikan cukup baik/cukup puas dengan nilai rata-rata sebesar $\mathbf{3 , 3}$ sebagaimana terlihat pada tabel berikut:

Tabel 8.Nilai Kinerja

Perspektif Masyarakat Pembayar Pajak (WPD)

\begin{tabular}{|c|c|c|c|}
\hline No. & Varibel Perspektif WPD & Nilai & Kategori \\
\hline 1. & Akuisisi WPD & 1 & \\
\hline 2. & Retensi WPD & 5 & \\
\hline 3. & Kepuasan WPD & 4 & \\
\hline & $\begin{array}{c}\text { Jumlah } \\
\text { Nilai Rata-rata }\end{array}$ & $\begin{array}{c}10 \\
\mathbf{3 , 3 3}\end{array}$ & Cukup Baik \\
\hline
\end{tabular}

Sumber: Data Penelitian, diolah kembali (2013). 


\section{Perspektif Proses Bisnis Internal}

Penilaian kinerja dengan perspektif proses bisnis dan internal dilakukan dengan membagikan kuesioner kepada 40 pegawai DPDPK, dari 40 responden mayoritas berumur 36-46 tahun sebanyak 42,5\%, berjenis kelamin wanita sebanyak $60 \%$, latar belakang pendidikan terakhir $47,5 \%$ adalah S1 sedangkan masa kerja responden mayoritas sudah lebih dari 10 tahun yaitu sebanyak $50 \%$.
Selanjutnya, penulis melakukan pengujian validitas dan reabilitas pada instrumen penelitian berupa kuesioner yang nantinya akan digunakan untuk menilai prespektif proses bisnis internal serta perspektif pertumbuhan dan pembelajaran. Berikut adalah rekapitulasi hasil pengujian validitas dan reabilitas kuesioner untuk prespektif proses bisnis internal yang terlihat pada tabel 9 berikut:

Tabel 9.

Hasil Uji Validitas

Perspektif Proses Bisnis Internal

\begin{tabular}{|c|c|c|c|c|}
\hline No. & Variabel/Indikator & r hitung & $r$ tabel & Keterangan \\
\hline \multirow[t]{8}{*}{1.} & Sarana dan Prasarana & & & \\
\hline & 1 & 0.371 & 0.312 & Valid \\
\hline & 2 & 0.541 & 0.312 & Valid \\
\hline & 3 & 0.347 & 0.312 & Valid \\
\hline & 4 & 0.707 & 0.312 & Valid \\
\hline & 5 & 0.418 & 0.312 & Valid \\
\hline & 6 & 0.611 & 0.312 & Valid \\
\hline & 7 & 0.640 & 0.312 & Valid \\
\hline
\end{tabular}

2. Proses

Kedisiplinan Pegawai

$\begin{array}{llll}1 & 0.713 & 0.312 & \text { Valid } \\ 2 & 0.463 & 0.312 & \text { Valid } \\ 3 & 0.513 & 0.312 & \text { Valid } \\ 4 & 0.565 & 0.312 & \text { Valid } \\ 5 & 0.770 & 0.312 & \text { Valid }\end{array}$

Ketepatan Penyampaian Laporan

$\begin{array}{lll}0.383 & 0.312 & \text { Valid } \\ 0.480 & 0.312 & \text { Valid } \\ 0.627 & 0.312 & \text { Valid } \\ 0.611 & 0.312 & \text { Valid } \\ 0.780 & 0.312 & \text { Valid }\end{array}$

Ketaatan Terhadap SOP

$\begin{array}{lll}0.641 & 0.312 & \text { Valid } \\ 0.651 & 0.312 & \text { Valid } \\ 0.680 & 0.312 & \text { Valid } \\ 0.325 & 0.312 & \text { Valid }\end{array}$




\begin{tabular}{cccc}
5 & 0.677 & 0.312 & Valid \\
Kinerja Pelayanan Internal & & 0.312 & Valid \\
1 & 0.494 & 0.312 & Valid \\
2 & 0.451 & 0.312 & Valid \\
3 & 0.612 & 0.312 & Valid \\
4 & 0.661 & 0.312 & Valid \\
5 & 0.529 & 0.312 & Valid \\
6 & 0.561 & 0.312 & Valid \\
7 & 0.666 & & Valid \\
Kepuasan Bekerja & & 0.312 & Valid \\
1 & 0.538 & 0.312 & Valid \\
2 & 0.424 & 0.312 & Valid \\
3 & 0.407 & 0.312 & Valid \\
4 & 0.677 & 0.312 & Valid \\
\hline 5 & 0.703 & 0.312 & \\
\hline
\end{tabular}

Sumber: Data Primer, Diolah 2014

Validitas adalah tingkat keandalan dan kesahihan alat ukur yang digunakan. Intrumen dikatakan valid berarti menunjukkan alat ukur yang dipergunakan untuk mendapatkan data itu valid atau dapat digunakan untuk mengukur apa yang seharusnya di ukur (Sugiyono, 2013:121). Suatu pernyataan dikatakan valid apabila nilai $r$ hitung lebih besar dari $r$ tabel untuk degree of freedom $(\mathrm{df})=\mathrm{n}-2$, dalam hal ini adalah jumlah sampel (Ghozali, 2011). Dari hasil pengujian validitas pada tabel 9 . tersebut terlihat bahwa semua indikator pada setiap item pertanyaan dalam kuesioner dinyatakan valid.
Uji reliabilitas berguna untuk menetapkan apakah instrumen yang dalam hal ini kuesioner dapat digunakan lebih dari satu kali, paling tidak oleh responden yang sama akan menghasilkan data yang konsisten. Instrumen penelitian dikatakan reliabel apabila nilai Cronbach's Alpha-nya lebih besar dari 70\% atau 0,70 (Ghozali, 2011). Dari hasil uji reabilitas dengan bantuan SPSS 16 diketahui bahwa semua indikator pertanyaan dalam kuesioner perspektif proses bisnis internal dinyatakan reliabel seperti terlihat dalam tabel 10 .

Tabel 10.

Hasil Uji Reabilitas

Perspektif Proses Bisnis Internal

\begin{tabular}{clcc}
\hline No. & \multicolumn{1}{c}{ Variabel } & Cronbach's Alpha & Keterangan \\
\hline 1. & Sarana dan Prasarana & 0.780 & Reliabel \\
2. & Proses & & \\
& Kedisiplinan Kehadiran Pegawai & 0.806 & Reliabel \\
& Ketepatan Penyampaian Laporan & 0.789 & Reliabel \\
& Ketaatan Terhadap SOP & 0.773 & Reliabel \\
& Kinerja Pelayanan Internal & 0.810 & Reliabel \\
3. & Kepuasan Bekerja & 0.776 & Reliabel \\
\hline
\end{tabular}

Sumber: Data Primer, Diolah 2014 
Kemudian untuk melihat jawaban responden dalam mendukung tujuan organisasi dalam memberikan pelayanan dan pertanggungjawaban yang optimal terhadap masyarakat, dilakukan analisis deskriptif terhadap jawaban responden dalam kuesioner. Berdasarkan hasil penjelasan distribusi jawaban responden pada masing- masing variabel dalam perspektif proses bisnis internal tersebut, sebagian besar responden menyatakan cukup puas atas upaya DPDPK dalam mendukung tujuan organisasi dengan nilai rata-rata sebesar 3,96 sebagaimana ditunjukkan oleh tabel 11 berikut:

Tabel 11.

Nilai Perspektif Proses Bisnis Internal

\begin{tabular}{clcc}
\hline No. & \multicolumn{1}{c}{ Variabel } & Nilai Rata-rata & Kategori \\
\hline 1. & Sarana dan Prasarana & 3,91 & \\
2. & Proses & 3,84 & \\
3. & Kepuasan Bekerja & 4,12 & \\
\hline \multicolumn{2}{r}{ Rata-rata } & $\mathbf{3 , 9 6}$ & Cukup Baik \\
\hline
\end{tabular}

Sumber: Data Primer, Diolah 2014

Dari tabel 11. tersebut, nilai terendah perspektif proses bisnis internal terletak pada variabel proses yaitu sebesar 3,84 yang menyangkut kedisiplinan kehadiran pegawai, ketepatan penyampaian laporan, ketaatan terhadap Prosedur Operasi Standar (POS) serta kinerja pelayanan internal.

\section{Perspektif Pertumbuhan dan Pembelajaran}

Pada perspektif ini, pengukuran dilakukan dengan 4 tolok ukur penilaian kinerja yang meliputi: retensi pegawai, motivasi kerja pegawai, kesempatan mengembangkan diri, inovasi dan suasana dalam bekerja. Variabel retensi pegawai dinilai dengan menggunakan perbandingan jumlah karyawan yang masuk dan keluar selama tahun 2009-2012, sedangkan untuk ketiga variabel sisanya dinilai dengan menggunakan kuesioner yang dibagikan kepada 40 pegawai DPDPK. Responden dalam persepektif pertumbuhan dan pembelajaran adalah sama dengan yang responden pada perspektif proses bisnis dan internal.

Berdasarkan hasil uji validitas dan reabilitas, kuesioner dalam perspektif pertumbuhan dan pembelajaran dinyatakan valid dan reliabel, seperti terlihat pada tabel 12 dan tabel 13 .

Tabel 12.

Hasil Uji Validitas

Perspektif Pertumbuhan dan Pembelajaran

\begin{tabular}{ccccc}
\hline No. & Variabel/Indikator & $\mathbf{r}$ hitung & $\mathbf{r}$ tabel & Keterangan \\
\hline 1. & Motivasi Kerja Pegawai & & & \\
1 & 0.568 & 0.312 & Valid \\
2 & 0.606 & 0.312 & Valid \\
3 & 0.530 & 0.312 & Valid \\
4 & 0.701 & 0.312 & Valid \\
5 & 0.640 & 0.312 & Valid \\
6 & 0.533 & 0.312 & Valid \\
7 & 0.490 & 0.312 & Valid
\end{tabular}

2. Kesempatan Mengembangkan Diri
1
0.489
0.312
Valid 


\begin{tabular}{cccc}
2 & 0.499 & 0.312 & Valid \\
3 & 0.803 & 0.312 & Valid \\
4 & 0.798 & 0.312 & Valid \\
5 & 0.573 & 0.312 & Valid \\
$3 . \quad$ Inovasi & & & \\
1 & 0.562 & 0.312 & Valid \\
2 & 0.733 & 0.312 & Valid \\
3 & 0.768 & 0.312 & Valid \\
4 & 0.787 & 0.312 & Valid \\
5 & 0.457 & 0.312 & Valid \\
$4 . \quad$ Suasana Dalam Bekerja & & & \\
1 & 0.402 & 0.312 & Valid \\
2 & 0.497 & 0.312 & Valid \\
3 & 0.776 & 0.312 & Valid \\
4 & 0.655 & 0.312 & Valid \\
5 & 0.659 & 0.312 & Valid \\
6 & 0.668 & 0.312 & Valid \\
\hline
\end{tabular}

Sumber: Data Primer, Diolah 2014

Tabel 13.

Hasil Uji Reabilitas

Perspektif Pertumbuhan dan Pembelajaran

\begin{tabular}{clcc}
\hline No. & \multicolumn{1}{c}{ Variabel } & Cronbach's Alpha & Keterangan \\
\hline 1. & Motivasi Kerja Pegawai & 0.824 & Reliabel \\
2. & Kesempatan Mengembangkan Diri & 0.826 & Reliabel \\
3. & Inovasi & 0.849 & Reliabel \\
4. & Suasana Dalam Bekerja & 0.822 & Reliabel \\
\hline
\end{tabular}

Sumber: Data Primer, Diolah 2014

Dari jumlah pegawai DPDPK Kota Yogyakarta yang masuk dan keluar diketahui bahwa retensi pegawai dari tahun 2009-2011 terus mengalami peningkatan setiap tahunnya, sedangkan untuk tahun 2012 mengalami penurunan. Keluarnya pegawai DPDPK sendiri lebih dikarenakan pegawai yang bersangkutan telah memasuki masa pensiun. Dengan skala likert retensi pegawai DPDPK Kota Yogyakarta dinilai kurang dan diberi skor $\mathbf{1}$.

Motivasi kerja pegawai merupakan variabel yang menggambarkan tingkat kepuasan pegawai DPDPK atas kebijakan-kebijakan yang diterapkan pada organisasi. Distribusi jawaban responden menunjukkan sebagian besar responden menyatakan termotivasi dalam bekerja, dengan menggunakan skala likert nilai rata-rata tingkat motivasi pegawai dalam bekerja didapat hasil sebesar 3,98 atau dapat dikategorikan pegawai cukup termotivasi.

Variabel kesempatan mengembangkan diri menggambarkan tingkat kepuasan pegawai DPDPK atas program-program pengembangan diri yang diterapkan organisasi. Dalam variabel kesempatan pengembangan diri, distribusi jawaban responden secara keseluruhan menunjukkan tingkat kepuasan yang tinggi yaitu sebanyak $58 \%$ responden menyatakan setuju dengan sistem yang diterapkan organisasi dalam mengembangkan kapasitas sumber daya manusia di DPDPK. Dengan menggunakan 
skala likert secara umum didapat nilai ratarata tingkat kepuasan responden terhadap kesempatan pengembangan diri yang diterapkan DPDPK sebesar 3,82 atau dapat dikategorikan setuju.

Inovasi merupakan variabel yang menunjukkan adanya kesempatan bagi pegawai DPDPK untuk kreatif dan menemukan hal-hal baru dalam upaya peningkatan pelayanan kepada masyarakat. Pada variabel inovasi, distribusi jawaban responden secara keseluruhan menyatakan bahwa sebagain besar pegawai telah melakukan inovasi dalam bekerja dengan presentase jawaban setuju sebesar 71,5 \%. Dengan menggunakan skala likert, maka nilai rata-rata tingkat inovasi pegawai DPDPK adalah sebesar $\mathbf{3 , 8 5}$ atau dapat dikategorikan setuju.

Dari hasil penjelasan tiap variabel yang menjadi tolok ukur perspektif pertumbuhan dan pembelajaran tersebut, maka secara umum hasil akhir penilaian kinerja untuk perspektif ini dapat dilihat pada tabel 14 .

Tabel 14.

Nilai Perspektif Pertumbuhan dan Pembelajaran

\begin{tabular}{clcc}
\hline No. & \multicolumn{1}{c}{ Variabel } & $\begin{array}{c}\text { Nilai } \\
\text { Rata-rata }\end{array}$ & Kategori \\
\hline 1. & Retensi Pegawai & 1 & \\
2. & Motivasi Kerja & 3,98 & \\
3. & Kesempatan Mengembangkan Diri & 3,82 & \\
4. & Inovasi Pegawai & 3,85 & \\
5. & Suasana dalam Bekerja & 3,87 & \\
\hline & Rata-rata & $\mathbf{3 , 3 0}$ & Cukup Baik \\
\hline
\end{tabular}

Sumber: Data Primer, Diolah 2014

Hasil Pengukuran Kinerja dengan Kota Yogyakarta secara keseluruhan selama Balance Scorecard tahun 2009-2012 berdasarkan masingBerdasarkan penilaian kinerja dengan empat masing perspektif dapat dilihat pada tabel 15 . perspektif di atas, maka hasil kinerja DPDPK berikut:

Tabel 15.

Rekapitulasi Hasil Pengukuran Kinerja DPDPK Kota Yogykarta Dengan Metode Balance Scorecard

\begin{tabular}{|c|c|c|c|c|c|}
\hline No. & Perspektif & Tolok Ukur & $\begin{array}{l}\text { Nilai Per } \\
\text { Variabel }\end{array}$ & $\begin{array}{c}\text { Nilai } \\
\text { Kinerja } \\
\text { Akhir } \\
\end{array}$ & $\begin{array}{c}\text { Nilai } \\
\text { Kinerja } \\
\text { Akhir (\%) } \\
\end{array}$ \\
\hline \multirow{3}{*}{1.} & \multirow{3}{*}{ Keuangan } & a. Rasio Ekonomis & 3 & \multirow{7}{*}{4,33} & 60 \\
\hline & & a. Rasio Efektivitas & 5 & & 100 \\
\hline & & b. Rasio Efisiensi & 5 & & 100 \\
\hline \multirow{4}{*}{2.} & \multicolumn{2}{|c|}{ Jumlah Skor } & 13 & & 86,6 \\
\hline & Masyarakat & a. Akuisisi WPD & 5 & & 100 \\
\hline & \multirow{2}{*}{$\begin{array}{c}\text { Pembayar Pajak } \\
\text { (WPD) }\end{array}$} & b. Retensi WPD & 1 & & 20 \\
\hline & & c. Kepuasan WPD & 4 & & 80 \\
\hline \multirow{5}{*}{3.} & \multicolumn{2}{|c|}{ Jumlah Skor } & 10 & \multirow[t]{4}{*}{3,33} & 66,6 \\
\hline & \multirow{3}{*}{$\begin{array}{l}\text { Proses Bisnis } \\
\text { Internal }\end{array}$} & a. Sarana \& Prasarana & 3,91 & & 78,2 \\
\hline & & b. Proses & 3,84 & & 76,8 \\
\hline & & c. Kepuasan Bekerja & 4,12 & & 82,4 \\
\hline & \multirow{4}{*}{$\begin{array}{l}\text { Pertumbuhan } \\
\text { dan } \\
\text { Pembelajaran }\end{array}$} & mlah Skor & 11,87 & \multirow[t]{4}{*}{3,96} & 79,13 \\
\hline \multirow{3}{*}{4.} & & a. Retensi Pegawai & 1 & & 20 \\
\hline & & b. Motivasi Kerja & 3,98 & & 79,6 \\
\hline & & $\begin{array}{l}\text { c. Kesempatan } \\
\text { Mengembangkan Diri }\end{array}$ & 3,82 & & 76,4 \\
\hline
\end{tabular}




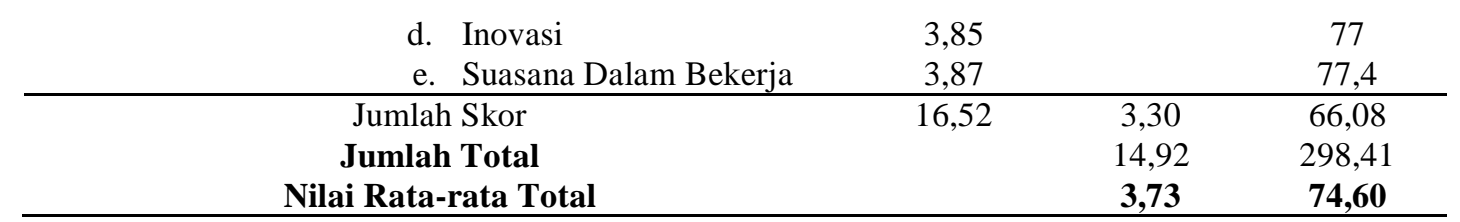

sumber: data penelitian yang diolah kembali

Pada tabel 15. tersebut menunjukkan bahwa nilai tertinggi kinerja DPDPK terletak pada perspektif keuangan yaitu sebesar 4,33 atau $86,6 \%$ dan nilai kinerja terendah ada pada perspektif pertumbuhan dan pembelajaran yaitu sebesar 3,30 atau 66,08\%. Dengan demikian, secara keseluruhan nilai capaian akhir kinerja DPDPK Kota Yogyakarta selama 4 tahun (2009-2012) adalah sebesar $\mathbf{3 , 7 3}$ atau $\mathbf{7 4 , 6 0 \%}$ dan dengan menggunakan skala likert maka nilai kinerja tersebut termasuk dalam kategori Cukup Baik.

\section{SIMPULAN}

\section{Kesimpulan}

Berdasarkan hasil pembahasan dan analisis data yang telah dijelaskan sebelumnya, maka dapat ditarik kesimpulan sebagai berikut:

1. Metode balance scorecard dapat diterapkan pada DPDPK Kota Yogyakarta sebagai tolok ukur pengukuran kinerja organisasi karena DPDPK sendiri telah memformulasikan visi, misi, dan strategi organisasinya dengan jelas.

2. Penilaian kinerja DPDPK Kota Yogyakarta dari perspektif keuangan dinilai baik dengan nilai rata-rata sebesar 4,33 menunjukkan bahwa DPDPK mampu mengelola anggaran pendapatan dan belanjanya secara efektif dan efisien.

3. Pada perspektif masyarakat pembayar pajak, kinerja DPDPK dikategorikan cukup baik dengan nilai rata-rata sebesar 3,3 yang berarti bahawa DPDPK dinilai telah mampu memberikan tingkat kepuasan yang cukup kepada wajib pajak daerah.

4. Pada perspektif proses bisnis internal, kinerja DPDPK dinilai cukup baik dengan nilai rata-rata sebesar 3,96 dengan nilai terendah pada variabel proses yang menyangkut kedisiplinan kehadiran pegawai, ketepatan penyampaian laporan, ketaatan terhadap Prosedur Operasi Standar (POS), dan kinerja pelayanan internal. Melalui kuesioner yang dibagikan kepada 40 pegawai DPDPK sebagai respondennya diketahui bahwa sebagian besar responden menyatakan cukup puas atas upaya DPDPK dalam mendukung tujuan organisasi.

5. Pada perspektif pertumbuhan dan pembelajaran, secara umum nilai ratarata kinerja DPDPK adalah 3,30 atau dikategorikan cukup baik. Nilai ratarata terendah terletak pada variabel retensi pegawai yang berarti bahwa jumlah pegawai yang keluar dari tahun ke tahun semakin banyak. Hal tersebut dikarenakan banyak pegawai DPDPK yang telah memasuki masa pensiun.

6. Secara keseluruhan, penilaian kinerja DPDPK Kota Yogyakarta dengan metode balance scorecard dalam kurun waktu 4 tahun (2009-2012) dinyatakan cukup baik dengan skor rata-rata sebesar 3,73 atau $74,60 \%$. Nilai kinerja akhir DPDPK yang berada pada kisaran $70 \%-80 \%$ tersebut mengindikasikan bahwa masih banyak hal yang harus ditingkatkan oleh DPPDK dalam memberikan pelayanan maupun pertanggungjawabannya kepada masyarakat. Selain itu, kategori kinerja DPDPK yang cukup baik juga menunjukkan bahwa DPDPK belum secara maksimal melaksanankan program/kegiatan yang ada dalam rencana strategis organisasi. 


\section{Implikasi}

Berdasarkan hasil penelitian ini didapat beberapa hasil temuan yang berimplikasi untuk penelitian-penelitian selanjutnya, antara lain:

1. Aspek penyebab tinggi rendahnya retensi pegawai pada organisasi sektor publik berbeda dengan sektor swasta. Pada sektor swasta, tingkat retensi pegawai pada umumnya dipengaruhi oleh aspek internal perusahaan seperti suasana dalam bekerja dan tingkat kompensasi/gaji yang diberikan oleh perusahaan. Sedangkan dalam penelitian ini, tingkat retensi pegawai DPDPK lebih disebabkan oleh banyaknya pegawai dinas yang telah memasuki masa pensiun.

2. Dalam penelitian ini diketahui bahwa hasil kinerja pada perspektif keuangan tidak dipengaruhi secara langsung oleh hasil kinerja pada ketiga perspektif lainnya. Berdasarkan hasil penelitian ini nilai tertinggi terletak pada perspektif keuangan, namun hal tersebut tidak diikuti dengan nilai yang sama pada ketiga perspektif lainnya. Artinya, kinerja organisasi sektor publik yang baik dilihat dari perspektif keuangan belum tentu menggambarkan kepuasan yang tinggi pula bagi masyarakat sehingga organisasi sektor publik masih perlu meningkatkan kinerja organisasinya dengan melakukan peningkatan pelayanan kepada masyarakat melalui pengoptimalan keterampilan dan keahlian sumber daya manusianya maupun pembenahan sistem kinerja internal organisasinya.

Berdasarkan temuan-temuan tersebut dapat disimpulkan bahwa pengukuran kinerja pada organisasi sektor swasta berbeda dengan pengukuran kinerja pada organisasi sektor publik dimana tujuan utamanya terletak pada perspektif wajib pajak daerah bukan perspektif keuangan. Hal tersebut mendukung teori strategy mapping balance scorecard pada organisasi sektor publik yang telah dirumuskan sebelumnya oleh Robertson.

\section{Keterbatasan Penelitian}

Penelitian ini memiliki beberapa

keterbatasan, antara lain:

1. Penilaian kinerja pada perspektif pertumbuhan dan pembelajaran belum dilakukan secara menyeluruh dikarenakan keterbatasan data berupa data pegawai DPDPK Kota Yogyakarta yang mengikuti pelatihan/diklat/seminar. Hal tersebut dikarenakan tidak adanya sistem administrasi pencatatan yang memadai serta berganti-gantinya pegawai yang bertanggung jawab atas urusan administrasi tersebut yang tidak meninggalkan salinan data/arsip.

2. Teknik pengumpulan data dalam penelitian ini (wawancara) masih terbatas. Peneliti belum bisa melakukan wawancara secara terstruktur untuk menggali informasi lebih mendalam berkaitan dengan obyek yang diteliti.

3. Penelitian ini tidak sampai mengukur outcomes atau dampak langsung bagi kinerja DPDPK Kota Yogyakarta di masa mendatang setelah adanya penelitain ini. Peneliti tidak melakukan penelusuran lebih lanjut kepada objek yang diteliti atas temuan-temuan dari hasil penelitian yang telah dilakukan.

\section{Saran}

Berdasarkan kesimpulan dan keterbatasan penelitian yang telah diuraikan tersebut, maka saran-saran yang dapat diberikan adalah sebagai berikut:

a. Bagi DPDPK Kota Yogyakarta

1) DPDPK Kota Yogyakarta sebaiknya lebih banyak meningkatkan kinerja dari perspektif pertumbuhan dan pembelajaran untuk meningkatkan kapabilitas sumber daya manusia dalam organisasi, salah satunya dengan cara memberikan pelatihan-pelatihan berkesinambungan kepada seluruh pegawai secara merata. 
2) DPDPK Kota Yogyakarta sebaiknya mulai melakukan pembenahan sistem administrasi tata usaha atau kearsipan agar jika sewaktu-waktu diperlukan, data-data dapat dengan mudah ditemukan. Hal tersebut juga sesuai dengan penilaian pada variabel proses dalam perspektif proses bisnis internal yang dinilai masih rendah daripada variabel lainnya. Selain itu, aspek kedisiplinan kehadiran pegawai, ketepatan penyampaian laporan, ketaatan terhadap Prosedur Operasi Standar (POS) serta kinerja pelayanan internal juga perlu ditingkatkan.

b. Bagi Penelitian Selanjutnya

1) Penelitian selanjutnya diharapkan dapat melakukan pengumpulan data empiris secara lengkap sehingga evaluasi kinerja organisasi sektor publik dapat dilakukan secara maksimal/menyeluruh.

2) Penelitian selanjutnya diharapkan dapat menambah variabel-variabel penelitian yang lain dan memperbanyak sampel yang ada.

3) Penelitian selanjutnya diharapkan dapat menggunakan teknik pengumpulan data yang lebih terstruktur dan menyeluruh agar informasi yang diperoleh dari obyek yang diteliti dapat menghasilkan hasil analisis data yang lebih akurat dan dapat dipercaya.

4) Variabel retensi pegawai pada perspektif pertumbuhan dan pembelajaran sebaiknya tidak lagi dijadikan indikator pengukuran kinerja pada organisasi pemerintahan (pegawai negeri sipil) karena faktor yang menyebabkan keluar masuknya pegawai pada organsasi pemerintahan lebih disebabkan karena pegawai telah memasuki masa pensiun bukan dipengaruhi langsung oleh lingkungan organisasi itu sendiri. Jadi, variabel ini kurang dapat dijadikan salah satu faktor yang dapat mendukung penilaian kinerja suatu organisasi sektor publik.

5) Sebaiknya pengukuran kinerja diukur sampai outcomes-nya sehingga dampak dari hasil penelitian terhadap obyek yang diteliti dapat diketahui secara langsung serta dapat dilakukan tahapan evaluasi.

\section{REFERENSI}

Arikunto, Suharsimi. 2010. Prosedur Penelitian: Suatu Pendekatan Praktek. Jakarta: Rineka Cipta.

Danim, Sudarwan. 2000. Metode Penelitian untuk Ilmu-Ilmu Perilaku. Jakarta: Bumi Aksara.

Gaspersz, Vincent. 2006. Balanance Scorecard Denngan Six Sigma Untuk Organisasi Bisnis dan Pemerintah. Jakarta: PT. Gramedia Pustaka Utama.

Ghozali, Imam. 2011. Aplikasi Analisis Multivarite dengan Program IBM SPSS. Cetakan V. Semarang : Badan Penerbit UNDIP.

Kaplan, Robert, S., Norton David, P. 1993. Putting the Balance Scorecard to Work. Harvard Bussiness Review.

Kaplan, Robert S., Norton David, P. 1996. Balance Scorecard: Translating Strategy into Action. Harvard Business School Press. Peter R.Yosi Pasla, M.B.A (penterjemah). 2000, Balance Scorecard : Menerapkan Strategi menjadi Aksi. Jakarta: Erlangga.

Mahsun, Mohammad, 2009. Pengukuran Kinerja Sektor Publik. Yogyakarta: BPFE.

Mahmudi. 2010. Manajemen Kinerja Sektor Publik. Yogyakarta: UPP STIM YKPN.

Mardiasmo. 2002. Akuntansi Sektor Publik. Yogyakarta: ANDI.

Pratiwi, Umi. 2010. Balance Scorecard dan Manajemen Strategik. Jurnal Ilmiah 11 (2): 166-174. 
JURNAL AKUNTANSI. VOL.2 NO.2 DESEMBER 2014

Rahmawati,dkk. 2006. Analisis Kinerja Organisasi Publik Dengan Metode Balance Scorecard. Jurnal Ilmu Administrasi dan Kebijakan Publik 3(1):78-88.

Sari, Lia. 2013. Balance Scorecard Pada Organisasi Sektor Publik (sebuah studi literatur). Jurnal Ilmiah 5(2): 15-23.

Sugiyono. 2010. Metode Penelitian Pendidikan: Pendekatan Kuantitatif, Kualitatif, dan HRD. Bandung: Alfabeta.

\section{Metode Penelitian} Kuantitatif, Kualitatif dan $R \& D$. Bandung: Alfabeta.

Suwardika, I Nyoman. 2011. Analisi Kinerja Organisasi Sektor Publik Menggunakan Balance Scorecard (Studi pada Badan Pendidikan dan Pelatihan Provinsi Jawa Timur). Publikasi Ilmiah. Universitas Brawijaya e Malang. 